WYCHOWANIE DO DOJRZAŁOŚCI CHRZEŚCIJAŃSKIEJ

Warszawskie Studia Pastoralne UKSW

Rok XI 2016 Nr 4(33)

ANGelika Wiech

\title{
IDEAŁ WYCHOWAWCY W PROCESIE ROZWOJU CNÓT MŁODEGO CZŁOWIEKA
}

Ideal teacher who can develop these virtues of the young man in the early periods of his life

\section{Wychowanie wielkim wyzwaniem}

Gdy dziecko przychodzi na świat, nie jest wstanie funkcjonować samodzielnie. Mleko matki i jej miłość są mu potrzebne do przeżycia i rozwoju. Jednak nie czas zatrzymywać się nad minimalnymi potrzebami człowieka, lecz spójrzmy na powołanie i cel dla którego człowiek przyszedł na świat. Każdego z ludzi Bóg stworzył na swoje podobieństwo wpisując $w$ jego serce piękne pragnienia i powołując do świętości (por. Jr 1, 5; Kpł 19, 2). Człowiek naznaczony grzechem pierworodnym wezwany jest, by każdego dnia mierzyć się z jego skutkami. Na drodze do świętości czyha wiele pułapek, trzeba więc czujności, nieustannej pracy nad sobą i mądrości, aby co dzień rozwijać w sobie to, co piękne nie poddając się słabościom. Złe skłonności człowieka nazywamy wadami, natomiast trwałe skłonności do dobra - cnotami. Szczególnie w pierwszych okresach życia człowieka, który dopiero uczy się wybierać to, co dobre, a odrzucać zło, potrzebna jest pomoc. Dziecko wymaga wychowania, prowadzenia przez kogoś, kto pomoże mu odróżnić dobro od zła, gdyż samo jeszcze nie jest wstanie kierować się obiektywną prawdą, lecz idzie za subiektywnymi uczuciami i pragnieniami. Dobrze taki stan rzeczy ukazuje troska ogrodnika o młode drzewo, które musi być chronione przed wiatrami, odpowiednio uprawiane, siłą prostowane, jeśli się wykrzywi, i podcinane, aby wydawało lepsze owoce. Tak samo człowiek wymaga 
troski najbliższych, od samego początku wychowuje samego siebie, a inni mu w tym pomagają. Pierwszymi wychowawcami są oczywiście rodzice, jednak także inni uczestniczą w tym procesie wychowania ${ }^{1}$.

Nauka zajmująca się wychowaniem to pedagogika. Nazwa ta pochodzi od greckich słów: pais - dziecko i ago - prowadzę, czyli prowadzić za rękę. Pierwotnie treścią tej dziedziny nauki było kształcenie osobowości dziecka na dobrach kultury. Paidagogos prowadził dziecko do szkoły, towarzyszył mu w zajęciach domowych oraz zabawach i podróżach. Wpływał na jego wychowanie przez swoją częstą obecność ${ }^{2}$. Współcześnie pedagogika jest nauką o wychowaniu, której celem jest wyposażenie społeczeństwa - szczególnie młodego pokolenia - w sprawności ogólne i zawodowe, w wiedzę, systemy wartości, zachowania, postawy i oddziaływanie na własny rozwój ${ }^{3}$. Wychowanie w wąskim znaczeniu to: „świadome, celowe i specyficzne pedagogiczne działanie osób z reguły występujących w różnych zbiorach (rodzinnych, szkolnych, innych) dokonywane głównie przez słowo (i inne postacie interakcji, zwłaszcza przez przykład osobisty) zmierzające do osiągnięcia względnie trwałych skutków (zmian) w rozwoju fizycznym, umysłowym, kulturowym i duchowym jednostki ludzkiej"4.

Będziemy więc czerpać z powyższej dziedziny nauki, szkicując ideał wychowawcy nastawionego na rozwijanie cnót w młodym człowieku. Pomimo, iż wychowanie trwa całe życie, skupimy się szczególnie na pierwszych trzech latach życia człowieka, ukazując płaszczyzny, możliwości i sposoby rozwoju cnót. Można by powiedzieć, że to dość nietypowy wiek i że o świadomym rozwoju cnót można mówić dopiero po tym okresie. Właśnie dlatego, iż wiek ten jest tak często pomijany w procesie wychowania, przyjrzymy się

1 Por. A. Robaczewski, O cnotach $i$ wychowaniu, Lublin 1999, s. 14-15.

2 Por. W. Pomykało (red.), Pedagogika, w: W. Pomykało (red.), Encyklopedia pedagogiczna, Warszawa 1993, s. 535-536.

3 Por. W. Okoń (red.), Pedagogika, w: Słownik Pedagogiczny, Warszawa 1981, s. 222-223.

4 Por. W. Pomykało (red.), Wychowanie, w: Encyklopedia pedagogiczna, Warszawa 1997, s. 913. 
mu uważniej, odkrywając istotne momenty pierwszych dni życia, które rzutują później na dalsze życie człowieka, a które są miejscami rozwoju cnót lub wad. Zastanowimy się także na ile i czy w ogóle możliwe jest nauczenie człowieka cnoty. Jedna z greckich rozpraw filozoficznych próbująca odpowiedzieć na to pytanie przytacza m.in. taki dowód: „Jeśli ktoś nie nauczył się czegoś, to o niczym nie świadczy, jeśli natomiast był bodaj jeden taki, co się nauczył, to jest dowód, że można się nauczyć" ${ }^{\prime 2}$. Dzisiejszy postęp nauki niewątpliwie ukazuje efekty wychowania wzywając do odpowiedzialności za rozwój swoich podopiecznych ${ }^{6}$.

\section{Nauka cnoty}

Mówiąc o wychowaniu, musimy zakładać jego cel, czyli ukształtowanie młodego człowieka, który będzie zarówno piękny jak i dobry. Cnota (gr. $\dot{\alpha} \rho \varepsilon \tau \dot{\eta}$ - arete, łac. virtus) świadczy o sile i pięknie człowieka, jest przejawem panowania woli nad ciałem i jego pożądliwościami. Przez wieki ludzie pragnęli posiadać cnoty. W starożytności cnotę określano jako pewną sprawność, doskonałość władzy psychicznej, dzięki której wola jest ukierunkowana na cel - dobro ${ }^{7}$. Najwięksi filozofowie, tacy jak: Sokrates, Platon, Arystoteles, Epikur, Seneka, Epiklet, św. Augustyn, św. Tomasz z Akwinu i wiele innych większość swojego życia poświęcili na poszukiwaniu prawdy o pięknie duszy człowieka oraz dążyli to tego, by być dobrymi ludźmi, a więc cnotliwymi ${ }^{8}$. Czerpiąc z myśli filozofów, Kościół obecnie stworzył katalog cnót, dzieląc je na boskie (teologalne) i ludzkie (kardynalne). Pierwsze z nich to wiara, nadzieja, miłość. Dzięki nim człowiek uczestniczy w naturze Bożej, otrzymuje zdolność do życia z Bogiem (por. KKK 1812).

5 S. Wołoszyn (red.), Czy mądrości i cnoty można się nauczyć, w: Od wychowania pierwotnego do końca XVIII stulecia, t. I, Kielce 1995, s. 28.

6 Por. T. Bilicki, Dziecko i wychowanie w pedagogii Jana Pawła II, Kraków 2000, s. 19.

7 Por. M. Mróz, Mądrość cnót - drogą odzyskania smaku życia, w: Mądrość życia, Toruń 2003, s. 19.

8 Por. H. Majkrzak, Cnoty i wady, Kraków 2008, s. 39-50. 
Wiara (łac. fides) to cnota przez którą człowiek „wierzy w Boga i w to wszystko, co On nam powiedział i objawił, a co Kościół podaje nam do wierzenia, ponieważ Bóg jest samą prawdą" (KKK 1814). Przedmiotem wiary jest świat niewidzialny, podnosi więc ona ludzki umysł do tego, co Boskie, pozwalając poznać prawdy jakie Bóg objawił. Cnota ta nie jest wynikiem abstrakcji czy czysto ludzkiego rozumowania, lecz darem samego Boga, który ukazał siebie człowiekowi. Przeciwnością cnoty wiary jest: niewiara, herezja, odstępstwo, bluźnierstwo9.

Nadzieja (łac. spes) jest cnotą „dzięki której pragniemy Królestwa niebieskiego i życia wiecznego, pokładając ufność w obietnicach Chrystusa i opierając się nie na naszych siłach, ale na pomocy łaski Ducha Świętego" (KKK 1817). Pragnienie człowieka skierowane jest więc na wieczne życie z Bogiem i utrzymywane jest dzięki tej cnocie pomimo wydarzeń czy trudności, które są doświadczeniem każdego dnia. Dotyczy więc tego, co przed nami i zapewnia osiągnięcie i spełnienie najgłębszych pragnień serca ludzkiego, czyli przebywania z wieczną Miłością. Różni się ona jednak od nadziei naturalnej, związanej z osiąganiem dóbr tego świata, która niknie wraz z jego przemijaniem $^{10}$.

Miłość (łac. caritas) to cnota boska, która uzdalnia nas do miłowania „Boga nade wszystko dla Niego samego, a naszych bliźnich jak siebie samych ze względu na miłość Boga" (KKK 1822). Ożywia ona serce człowieka, inspirując go do prawdziwej miłości; jest źródłem praktykowania każdej innej cnoty. Jest „więzią doskonałości” (1 Kor $13,14)$ łączącą i porządkującą cnoty pomiędzy sobą. Przewyższa ona inne cnoty: „Tak więc trwają wiara, nadzieja i miłość - te trzy, z nich zaś największa jest miłość" (1 Kor 13, 13). Jej źródłem jest sam Bóg, który kocha miłością doskonałą. Z miłości, jak ze źródła, wypływają: miłosierdzie, dobroczynność, jałmużna, upomnienie braterskie, poświęcenie życia dla innych itp. Przeciwieństwem miłości są

\footnotetext{
9 Por. tamże, s. 56-58.
}

10 Por. tamże, s. 59-60. 
m.in.: nienawiść, pożądanie, niezgoda, wojna, rozłam, poniżanie, zazdrość ${ }^{11}$.

Cnoty boskie, ukazujące prymat łaski Boga, pobudzają moralne działanie chrześcijanina, gdyż: „wiara bez uczynków jest martwa” (Jk 2, 26). Cnoty teologalne przenikają więc cnoty kardynalne, które z kolei mocno oparte są na wysiłku człowieka i wyrażają się w konkretnych czynach ${ }^{12}$. Cnoty ludzkie są „trwałymi postawami, stałymi dyspozycjami, habitualnymi zaletami umysłu i woli, które regulują nasze czyny, porządkują nasze uczucia i kierują naszym postępowaniem zgodnie z rozumem i wiarą" (KKK 1804). Cnoty te nie są czymś wrodzonym, lecz jak wskazuje nazwa (łac. habitus - nawyk), trzeba je zdobyć przez ćwiczenie stałej zdolności woli do czynienia dobra, przez działanie moralne ${ }^{13}$. Mówiąc o cnotach kardynalnych, istotną rzeczą jest zasada „złotego środka”, która nie odnosi się do cnót boskich, gdyż nie można np. kochać za bardzo. Mówi ona o tym, że w przypadku cnót ludzkich cnota znajduje się pośrodku, pomiędzy tym, co jest nadmiarem, a tym, co jest niedostatkiem, np. męstwa nie można utożsamiać ani z zuchwalstwem, ani z tchórzostwem, lub umiarkowanie nie jest ani obżarstwem, ani brakiem troski o własne zdrowie w wymiarze jedzenia ${ }^{14}$. Wszelakie cnoty ludzkie znajdują się wokół czterech podstawowych: roztropności, sprawiedliwości, umiarkowania i męstwa.

Roztropność (łac. prudentia) to cnota, która „uzdalnia rozum praktyczny do rozeznawania w każdej okoliczności naszego prawdziwego dobra i do wyboru właściwych środków do jego pełnienia" (KKK 1805). Uzdalnia ona rozum do kierowania się własnym osądem i nakazem poprzez odniesienie się do rzeczy potrzebnych do osiągnięcia celu jakim jest dobro ${ }^{15}$. Roztropność zbliżona jest do mądrości

\footnotetext{
11 Por. tamże, s. 61-67.

12 Por. M. Mróz, Człowiek w dynamizmie cnoty, Toruń 2001, s. 576-577.

13 Por. T. Ślipko, Zarys etyki ogólnej, Kraków 2004, s. 398.

14 Por. A. Siemianowski, Szkice z etyki wartości, Gniezno 1995, s. 61.

15 Por. M. Mróz, Człowiek w dynamizmie cnoty, dz. cyt., s. 617.
} 
ukazywanej w Biblii, która prowadzi do szczęścia ${ }^{16}$. Dzięki tej cnocie decyzje człowieka nie są automatyczne, lecz oparte na zdobytym doświadczeniu i mądrości. Celem roztropności jest odpowiednio kierować wolną wolą człowieka, dobrze ją wykorzystując. Człowiek wyznacza cel i kierunek własnego życia, którym dla chrześcijanina powinna być miłość Boga i bliźniego jak siebie samego. Roztropność jest zwana także „cnotą cnót”, ponieważ porządkuje ona rzeczy, nakierunkowując na dobro ${ }^{17}$.

Sprawiedliwość (łac. iustitia) to cnota polegająca na „stałej i trwałej woli oddawania Bogu i bliźniemu tego, co im się należy” (KKK 1807). Uzdalnia ona do bycia bezstronnym wobec ludzi i wspólnych dóbr. Nie polega na równym obdarowywaniu, ale zgodnym $z$ konkretnymi potrzebami człowieka. Św. Tomasz z Akwinu wiązał cnotę sprawiedliwości z miłością oraz ukazywał, że „stworzenie nie jest samo w sobie aktem sprawiedliwości; stworzenie nie należy się nikomu"18. Piękno owej cnoty wyraża się w trosce nie tyle o swoje dobro, ile o dobro innych ludzi, przez co wyraża się heroiczna miłość do Boga i bliźnich. Podstawą sprawiedliwości jest równość i godność każdego człowieka ${ }^{19}$.

Umiarkowanie (łac. temperantia) „pozwala opanować dążenie do przyjemności i zapewnia równowagę w używaniu dóbr stworzonych. Umacnia panowanie woli nad popędem i utrzymuje pragnienia w granicach godziwości" (KKK 1809). Cnota ta dyscyplinuje pożądania człowieka, poddając je kierownictwu rozumu i woli ${ }^{20}$. Dzięki umiarkowaniu człowieka „nie daje się uwieść..., by iść za zachciankami swego serca” (Syr 5, 2; 37, 27-31). Sedno cnoty umiarkowania bardzo dobrze obrazuje tekst z Listu do Galatów: „Ciało bowiem do czego

\footnotetext{
16 Por. D. Szupryczyński, Cnota roztropności-prudentia, w: M. Mróz (red.), Cnoty kardynalne, Toruń 2000, s. 78.

17 Por. R. Adamczyk, Roztropność, w: E. Materski (red.), Cnoty - ich źródłem i celem jest miłość, Radom 2009, s. 42-44.

18 A. Kalinowski, Cnota sprawiedliwości - iustitia, w: M. Mróz (red.), Cnoty kardynalne, dz. cyt., 94-95.

19 Por. Z. Niemierski, Sprawiedliwość, w: E. Materski (red.), Cnoty - ich źródłem i celem jest miłość, dz. cyt., s. 56-57.

20 Por. M. Mróz, Człowiek w dynamizmie cnoty, dz. cyt., s. 617.
} 
innego dąży niż duch, a duch do czego innego niż ciało... jest zaś rzeczą wiadomą jakie uczynki rodzą się z ciała: nierząd, nieczystość, wyuzdanie, niewłaściwa pogoń za zaszczytami, niezgoda, rozłamy, zazdrość, pijaństwo, hulanki i tym podobne" (Ga 5, 17-21). Św. Paweł ukazuje tym samym w owym liście skłonność ciała do nieumiarkowania i grzechu, a także ogromną potrzebę ćwiczenia się w cnocie, po to by duch panował nad ciałem, a nie odwrotnie.

Męstwo (łac. fortitudo) pozwala podporządkować sferę uczuciową i pożądawczą człowieka jego rozumowi i woli. Cnota męstwa „uzdalnia do przezwyciężania strachu, nawet strachu przed śmiercią, do stawiania czoła próbom i prześladowaniom. Uzdalnia nawet do wyrzeczenia się i do ofiary z życia w obronie słusznej sprawy «Pan moja moc i pieśń» (Ps 118, 14), «Na świecie doznacie ucisku, ale miejcie odwagę: Jam zwyciężył świat!» (J 16, 33)" (KKK 1808). Męstwo jest siłą pozwalającą w obliczu śmierci, czy doświadczeniu trudnych uczuć, takich jak lęk, gniew, smutek czy pożądanie opanować te uczucia i kierować się wolą. Pozwala ona być wyżej niż uczucia i kierować się miłością do Boga i bliźnich wyrażającą się w obronie człowieka, wartości i prawdy ${ }^{21}$. Męstwo uzdalnia człowieka, by nie poddawał się napotkanym trudnościom, lecz podejmował walkę i stawiał im czoła. Czyni ono człowieka mocnym nie we własnych oczach, ale przede wszystkim w oczach samego Boga ${ }^{22}$.

\section{Początki życia człowieka}

Ukazując ideał wychowawcy w procesie rozwoju cnót młodego człowieka, trzeba nam przedstawić poszczególne etapy życia dziecka w aspekcie biologicznym, psychicznym, społecznym i duchowym. Pierwszymi, bazowymi okresami człowieka zaczynającego swoje życie są poniższe okresy rozwojowe:

- OKRES PRENATALNY - ok. 40 tygodni:

- wyraźna dominacja biologiczna;

- organizm matki jest pierwszym środowiskiem dziecka;

- niezbędna jest stałość środowiska;

21 Por. J. Woroniecki, W szkole wychowania, Lublin 2008, s. 208.

${ }^{22}$ Por. M. Mróz, Człowiek w dynamizmie cnoty, dz.cyt., s. 618-620. 
- kształtuje się fenotyp (poprzez geny i wpływ środowiska);

- rozwijają się zmysły (dziecko słyszy, czuje...);

- powstaje pamięć (m.in. słuchowa);

- nastawienie rodziców, najbliższej rodziny do dziecka, wzajemne relacje między rodzicami mają wpływ na jego rozwój;

- najbardziej intensywny rozwój fizyczny (ok. 10 do 18 tyg. ciąży powstaje większość neuronów).

- OKRES OKOŁOPORODOWY, STADIUM NOWORODKA - ok. 1 miesiąc:

- następuje adaptacja, sprawny kontakt zarówno ze światem przedmiotów, jak i ludzi (głównie z matką i ojcem);

- przystosowanie do radykalnie zmienionych warunków życia;

- dochodzi do konfrontacji oczekiwań rodziców względem ich dziecka;

- dziecko i matka uczą się siebie na nowo;

- noworodek reaguje na docierające do niego wrażenia zmysłowe;

- główne potrzeby dziecka to: kontakt emocjonalny, bliskość, bezpieczeństwo, więź, sen, aktywność, łaknienie, wydalanie;

- noworodek poprzez usta poznaje różne obiekty;

- reakcja na twarz matki wyrażona „uśmiechem” poprzez grymas;

- płacz jest narzędziem oddziaływania na drugiego człowieka.

- OKRES NIEMOWLĘCY - pierwszy rok życia:

- podstawowym zadaniem tego okresu jest nawiązanie bliskiej więzi z przynajmniej jedną osobą i osiągnięcie poczucia zaufania, inaczej zwanego relacją przywiązania;

- potrzeba rozwinięcia nadziei poprzez zachowanie przez dziecko spokojnego obrazu świata;

- warunkiem powstania więzi jest szybkie i adekwatne reagowanie dorosłego na potrzeby dziecka;

- niemowlę posiada kompetencje umożliwiające mu kontakt z otoczeniem fizycznym i społecznym;

- dziecko stawia pierwsze kroki, rozwija zdolności lokomocyjne, pozwalające poruszać się w przestrzeni, coraz bardziej precyzyjnie manipuluje przedmiotami, zdobywając wiedzę o otaczającym świecie; 
- dziecko poznaje sposoby używania przedmiotów w interakcji $\mathrm{z}$ opiekunem, droga do przedmiotu odbywa się zawsze przez drugiego człowieka;

- pojawia się zachowania intencjonalne;

- dziecko zaczyna używać środków do realizacji celów (np. ciągnięcie obrusu po to, by zdobyć interesujący je przedmiot);

- komunikacja jest głównie niewerbalna: płacz, gaworzenie, krzyk, śmiech, gesty oraz następuje wypowiadanie pierwszych słów;

- dziecko zdobywa cnotę nadziei i ufności.

- OKRES PONIEMOWLĘCY - 2-3 rok życia:

- niemowlę naśladuje dorosłych, jest coraz bardziej spostrzegawcze;

- bada otoczenie za pomocą słów w związku z rozwojem mowy;

- eksperymenty z przedmiotami posługując się metodą prób i błędów;

- początek posługiwania się wyobrażeniem przedmiotu;

- poznanie nowego otoczenia w poczuciu bezpieczeństwa;

- w drugim roku życia następuje psychiczne rozdzielenie dziecka od opiekunów;

- zachodzi proces indywidualizacji i potrzeba autonomii, samodzielności;

- istotny rozwój motoryki;

- dziecko ciągle jest egoistyczne, przekonane, że wszyscy myślą jak ono;

- następuje „eksplozja nazywania”, dziecko zadaje coraz więcej pytań;

- celem tego okresu jest zdobycie autonomii, poczucia odrębności;

- kształtuje się odwaga bycia kimś niezależnym oraz świadomość własnego ciała i sprawstwa;

- istnieje amnezja dziecięca, pamięć autobiograficzna tworzy się dopiero od 3 roku życia, tak jak i świadomy rozwój moralny, czyli zależność od woli ${ }^{23}$.

23 Por. A. I. Brzezińska, K. Appelt, B. Ziółkowska, Psychologia rozwojowa człowieka, Sopot 2016, s. 124-241; S. Głaz, Doświadczenie religijne a osobowość, Kraków 2003, s. 71-75. 


\section{Idealny wychowawca w procesie rozwoju cnót}

Integralne wychowanie młodego człowieka opiera się głównie na autorytecie, który odznacza się mądrością, doświadczeniem życiowym i prawością. Relacja mistrza z uczniem polega przede wszystkim na wspólnym robieniu czegoś razem, głównie poprzez współuczestnictwo w działaniu tego, kto już umie to robić. Mówiąc więc o ideale wychowawcy w rozwoju cnót, podstawową rzeczą jest, aby to wychowawca był człowiekiem pełnym cnót, świadomie o nie zabiegającym, będącym wzorem osobowym dla swego wychowanka ${ }^{24}$. Mogliśmy spojrzeć całościowo na potrzeby dziecka w poszczególnych okresach początków jego życia, dzięki czemu możemy dostrzec jak dziecko jest „chłonne” już w pierwszej fazie życia, kiedy rozwija się jeszcze w łonie matki. Wówczas doświadcza głównie miłości, która jest bazą na dalsze lata życia. Pokrótce na podstawie powyższych treści, łącząc wiedzę z zakresu psychologii, biologii i aretologii z pedagogiką, ukazane zostaną sposoby i płaszczyzny wychowania młodego człowieka do życia cnotliwego, z podziałem na poszczególne cnoty.

- Cnota wiary w pierwszych okresach życia może rozwijać się poprzez:

- zapewnienie poczucia bezpieczeństwa dziecku;

- zaspokajanie podstawowych potrzeb wychowanka;

- realizację codziennych schematów;

- czas spędzany przez rodziców na modlitwie, postawy i świadectwo wiary;

- naukę prostych modlitw;

- rozwijanie ufności np. przez bliskość, troskę wychowawców, słowność.

- Cnota nadziei:

- zaspokajanie potrzeb dziecka;

- wypełnianie obietnic (np. bajka, słodycze jako nagroda po danej czynności);

- bliskość wychowawcy;

24 Por. A. Rynio, Integralne wychowanie w myśli Jana Pawła II, Lublin 2004, s. 193-194. 
- rozwijanie postawy ufności;

- pokój matki płynący z nadziei i oczekiwania przyjścia dziecka na świat.

- Cnota miłości:

- wytworzenie silnej więzi emocjonalnej między wychowawcą (przede wszystkim rodzicem) a dzieckiem;

- bliskość;

- okazywanie miłości poprzez przytulenie, karmienie, radość, zainteresowanie, czułe słowa, głaskanie;

- przygotowanie na przyjście dziecka na świat;

- relacja rodziców między sobą i Bogiem;

- błogosławienie dziecka;

- poświęcenie wychowawcy w celu zaspokojenia potrzeb dziecka.

- Cnota roztropności:

- dobre decyzje podejmowane przez matkę/wychowawcę (dziecko uczy się pomimo nieukształtowanej wolicjonalności, nabywając wzorce, które w następstwie mogą towarzyszyć mu przez całe życie);

- troskę o dziecko wyrażaną w karności;

- naukę rozeznawania dobra od zła;

- mądrą komunikację z dzieckiem, stały kontakt uczący otwartości na pouczenia innych;

- uczenie korzystania z doświadczeń dziecka np. oparzenie się, dotykanie niebezpiecznych sprzętów, ale także dobrych doświadczeń, np. aprobata przy nauce chodzenia, mowy.

- Cnota sprawiedliwości:

- modlitwę;

- kształtowanie poczucia godności;

- zauważanie, nazywanie i zaspokajanie potrzeb dziecka;

- naukę dzielenia się z innymi np. zabawką, jedzeniem;

- poświęcanie czasu każdemu według jego potrzeb (mężowi, dzieciom, bliskim, innym osobom);

- podejście pełne godności i sprawiedliwości względem każdego człowieka;

- trwałą wolę oddawania Bogu i bliźniemu tego, co im się należy. 
- Cnota umiarkowania:

- postawę matki podczas ciąży i karmienia piersią np. brak nałogów, odpowiednia dieta;

- troskę o zdrowe odżywianie dziecka, ograniczanie słodyczy;

- wsparcie dziecka i konsekwencja matki np. podczas etapu odstawiania od piersi;

- nieprzyzwalanie na wszystkie zachcianki dziecka;

- rozsądne dysponowanie czasem dziecka np. czas jedzenia, zabawy, nauki, sprzątania.

- Cnota męstwa:

- ból i trud znoszony z miłości do dziecka np. podczas ciąży, porodu, bezsennych nocy;

- poświęcenie wychowawcy, reagowanie na potrzeby dziecka pomimo zmęczenia i niechęci;

- uczenie cierpliwości i wytrwałości podczas nauki poszczególnych zdolności rozwojowych np. wyżynania zębów, nauki jedzenia, chodzenia;

- ukazywanie i bycie wzorem bezinteresownej ofiarności względem Boga i drugiego człowieka.

Podane sposoby rozwoju cnót młodego człowieka są syntezą powyższych rozważań i jedynie krótkim wskazaniem płaszczyzn owego rozwoju człowieka w kontekście kształtowania cnót. Łącząc ukazane powyżej treści z doświadczeniem życia, można wydobyć jeszcze mnóstwo cennych wskazówek dla wychowawców, którzy pragną wychować swoich podopiecznych na pięknych i cnotliwych ludzi.

\section{Streszczenie:}

Artykuł jest próbą ukazania sposobów i płaszczyzn zdobycia cnót przez młodego człowieka w pierwszych okresach jego życia (prenatalnym, noworodkowym, niemowlęcym i poniemowlęcym) oraz ukazania ideału wychowawcy, który będzie rozwijał owe cnoty w sowim wychowanku. Wolicjonalność potrzebna do rozwijania cnót, które zakładają użycie rozumu, powstaje dopiero po 3 roku życia, stąd pierwsze lata bywają często pomijane w perspektywie wychowania i aretologii. Artykuł porusza tę trudną płaszczyznę wczesnego dzieciństwa, kreśląc wagę tego okresu w procesie rozwoju cnót. 
Powyższe treści ukazują znaczenie wychowania jako wezwania do rozwoju cnót w swoim wychowanku, obszernie przedstawiają istotę każdej cnoty ujętej w katalogu cnót zgodnym z nauczaniem Kościoła katolickiego oraz ukazują syntezę poszczególnych etapów życia młodego człowieka, uwzględniając jego rozwój fizyczny, psychiczny, społeczny i duchowy.

\section{Summary:}

This article aims to show the ways and planes to acquire the virtues of the young man in the early periods of his life (prenatal, neonatal, infant and toddlers) and the ideal teacher who can develop these virtues in his pupil. Volitionality needed to develop the virtues that involve the use of reason arises only after the third year of life; since the early years are often overlooked in the perspective of education and erotology. This article raises that difficult plane early childhood, outlining the importance of this period in the development of virtues. These contents aim to show the importance of education as a call for the development of virtues in his pupil, amply illustrate the essence of every virtue included in the catalog of virtues consistent with the teachings of the Catholic Church and show the synthesis of the various stages of life of young man taking into account its physical, mental, social and spiritual.

Słowa klucze: ideał wychowawcy, cnota, wychowanie, rozwój, dziecko, wczesne dzieciństwo.

Key words: ideal educator, virtue, education, development, child, early childhood.

\section{Biogram:}

Angelika Wiech - lic. wychowania fizycznego, mgr teologii oraz pedagogiki resocjalizacyjnej i opiekuńczo-wychowawczej - absolwentka Akademii Wychowania Fizycznego w Katowicach, Instytutu Teologicznego w Częstochowie na wydziale Uniwersytetu Jana Pawła II w Krakowie oraz Uniwersytetu Kardynała Stefana Wyszyńskiego w Warszawie. Obecnie nauczyciel religii i doktorantka Teologii Pastoralnej UKSW.

\section{Bibliografia:}

Adamczyk R., Roztropność, w: Cnoty - ich źródłem i celem jest miłość, red. E. Materski, Radom 2009. 
Biblia Tysiąclecia, Poznań 2003.

Bilicki T., Dziecko i wychowanie w pedagogii Jana Pawła II, Kraków 2000.

Brzezińska A. I., Appelt K., Ziółkowska B., Psychologia rozwojowa człowieka, Sopot 2016.

Czy mądrości i cnoty można się nauczyć, w: Od wychowania pierwotnego do końca XVIII stulecia (t. I), red. S. Wołoszyn, Kielce 1995.

Encyklopedia pedagogiczna, red. W. Pomykało, Warszawa 1993.

Encyklopedia pedagogiczna, red. W. Pomykało, Warszawa 1997.

Głaz S., Doświadczenie religijne a osobowość, Kraków 2003.

Kalinowski A., Cnota sprawiedliwości - iustitia, w: Cnoty kardynalne, red.

M. Mróz, Toruń 2000.

Katechizm Kościoła Katolickiego, Poznań 2002.

Majkrzak H., Cnoty i wady, Kraków 2008.

Mróz M., Człowiek w dynamizmie cnoty, Torun 2001.

Mróz M., Mądrość cnót - drogą odzyskania smaku życia, w: Mądrość życia, red. M. Mróz, Toruń 2003.

Niemierski Z., Sprawiedliwość, w: Cnoty - ich źródłem i celem jest miłość, red. E. Materski, Radom 2009.

Robaczewski A., O cnotach i wychowaniu, Lublin 1999.

Rynio A., Integralne wychowanie w myśli Jana Pawła II, Lublin 2004.

Siemianowski A., Szkice z etyki wartości, Gniezno 1995.

Słownik Pedagogiczny, red. W. Okoń, Warszawa 1981.

Szupryczyński D., Cnota roztropności - prudentia, w: Cnoty kardynalne, red. M. Mróz, Toruń 2000.

Ślipko T., Zarys etyki ogólnej, Kraków 2004.

Woroniecki J., W szkole wychowania, Lublin 2008. 